\title{
ANALISIS PERBANDINGAN KEBIJAKAN PENYELESAIAN PERKARA PIDANA DI LUAR PERSIDANGAN DI BELANDA, INGGRIS, DAN INDONESIA
}

\author{
Ahmad Hajar Zunaidi ${ }^{1 *}$, Mokhammad Najih ${ }^{2}$ \\ 1* Kejaksaan Tinggi Sulawesi Tenggara, Indonesia, ahmadhajar1979@yahoo.com \\ ${ }^{2}$ Law Faculty, University of Muhammadiyah Malang, Malang, Indonesia najih@,umm.ac.id
}

\begin{abstract}
Abstrak: Tindak pidana yang bersifat ringan harus diselesaikan dengan mekanisme yang sama seperti tindak pidana yang berat, adalah salah satu bentuk ironi keadilan. Untuk mengurangi persoalan ironi keadilan tersebut, beberapa negara telah mengembangkan berbagai mekanisme penyelesaian perkara di luar persidangan untuk perkara-perkara yang bersifat ringan. Selain itu, sistem peradilan pidana di setiap negara secara umum juga hanya mampu memproses sebagian kecil dari seluruh tindak pidana yang terjadi sehingga penuntut umum harus melaksanakan diskresi dalam memutuskan perkara mana yang akan dilanjutkan atau dihentikan penuntutannya atau diselesaikan dengan mekanisme penyelesaian perkara pidana yang bersifat ringan di luar persidangan. Isu hukum yang dianalisis dalam tulisan ini adalah bagaimana ratio legis pengaturan mekanisme penyelesaian perkara pidana di luar persidangan di Belanda dan Inggris. Hasil dari analisis tersebut adalah ratio legis pengaturan penyelesaian perkara pidana di luar persidangan adalah untuk mewujudkan keadilan melalui penyederhanaan sistem peradilan pidana dan penerapan asas kelayakan. Keadaan berbeda terjadi pada sistem peradilan pidana Indonesia karena sangat tidak efisien, tidak sesuai dengan asas peradilan cepat, sederhana, dan biaya ringan. Berdasarkan kesimpulan diatas, maka dapat disampaikan rekomendasi bahwa asas kelayakan perlu segera diterima dalam sistem peradilan pidana di Indonesia dengan cara mengadopsi teori subsosialitas sebagaimana tercantum dalam Pasal 9a Sr. dan mengadopsi mekanisme penyelesaian perkara tindak pidana yang bersifat ringan di luar persidangan dalam bentuk transaksi dengan model komposisi, dengan disertai adanya modifikasi penambahan pokok-pokok pemikiran adaptasi bagi sistem hukum Indonesia.
\end{abstract}

Kata Kunci: Penyelesaian; Perkara; Pidana.

\section{PENDAhuluan}

Persoalan ironi keadilan, yang sering dinyatakan dengan kalimat bahwa hukum tumpul ke atas namun sangat tajam ke bawah, bukan hanya terkait disparitas sanksi pidana yang dijatuhkan yakni pelaku tindak pidana yang bersifat ringan dipidana dengan sangat berat, sedangkan pelaku tindak pidana yang berat dipidana dengan pidana yang ringan, namun juga terkait proses penyelesaian perkara tersebut. Tindak pidana yang bersifat ringan harus diselesaikan dengan mekanisme yang sama seperti tindak pidana yang berat, adalah salah satu bentuk ironi keadilan. Untuk mengurangi persoalan ironi keadilan tersebut, beberapa negara telah mengembangkan berbagai mekanisme penyelesaian perkara di luar persidangan untuk perkara-perkara yang bersifat ringan.

Pertimbangan lain urgensi pengembangan mekanisme penyelesaian perkara pidana di luar persidangan adalah karena sistem peradilan pidana di setiap negara secara umum hanya mampu memproses sebagian kecil dari seluruh tindak pidana yang terjadi (UN Office on Drugs and Crime, 2007). Jika suatu negara menyelidiki, menuntut, mengadili, dan menghukum seluruh pelaku tindak pidana, maka setiap tahap dari sistem peradilan pidana tidak akan mampu 
Zunaidi, etc.

pp. 1-15
E-ISSN : 2723-2476

P-ISSN : 2723-1968

ACLJ, Vol.1, Issue 1, 2020 menangani atau memproses seluruh tindak pidana yang terjadi tersebut (UN Office on Drugs and Crime, 2007). Oleh karena itu, polisi dan penuntut umum yang akan membawa masuk pelaku tindak pidana ke dalam sistem peradilan pidana, harus melaksanakan diskresi dalam memutuskan perkara mana yang akan dilanjutkan atau dihentikan penuntutannya (UN Office on Drugs and Crime, 2007). Jika dilanjutkan penuntutannya, perkara mana yang sanksi pidananya akan dijatuhkan melalui tahap persidangan (judicial sanctions) dan perkara mana yang sanksi pidananya tidak harus melalui tahap persidangan (extrajudicial sanctions).

Solusi sistematis terhadap persoalan ironi keadilan tersebut adalah pengembangan mekanisme penyelesaian perkara pidana yang bersifat ringan dalam sistem hukum pidana Indonesia yang pelaksanaannya bertumpu pada pengaturan diskresi penuntutannya oleh jaksa / penuntut umum. Oleh karena itu isu hukum yang dianalisis dalam tulisan ini adalah bagaimana ratio legis pengaturan mekanisme penyelesaian perkara pidana di luar persidangan di Belanda dan Inggris. Hasil dari analisis terhadap ratio legis pengaturan mekanisme penyelesaian perkara pidana di luar persidangan tersebut, diharapkan dapat memberikan suatu preskripsi berupa visi dan arah kebijakan baru pengembangan mekanisme penyelesaian perkara pidana yang bersifat ringan dalam sistem hukum pidana Indonesia.

\section{METODE PENELITIAN}

\section{Jenis Penilitan}

Dalam penelitian ini, peneliti menggunakan jenis penelitian Hukum Normatif. Yang dimaksud dengan penelitian hukum normatif yaitu suatu proses dimana proses tersebut bertujuan untuk menemukan sutu aturan hukum, prinsip-prinsip hukum, maupun doktrindoktrin hukum guna menjawab isu hukum yang sedang dihadapi (Peter Mahmud Marzuki, 2009). Alasan peneliti menggunakan jenis penelitian normatif karena peneliti berharap dapat memberikan atau menghasilkan argumentasi, teori atau konsep baru sebagai deskripsi dari penyelesaian isu hukum yang telah diambil.

\section{Pendekatan Penelitian}

Pendekatan penelitian hukum harus dilakukan dalam melakukan penelitian, hal itu bertujuan untuk membantu peneliti dalam mendapatkan informasi dari berbagai aspek mengenai isu hukum yang sedang dicari jawabannya. Oleh karena itu maka penulis dalam hal ini menggunakan 3 pendekatan, yaitu:

a. pendekatan Undang-undang, yaitu dengan menelaah semua Undang-undang dan regulasi yang bersangkutan dengan isu hukum yang sedang ditangani atau pendekatan ini juga bisa disebut dengan pendekatan menggunakan legislasi dan regulasi (Peter Mahmud Marzuki, 2009).

b. Pendektan konseptuan, pendekatan ini akan mempelajari dari segi undang-undang, doktrindoktrin didalam ilmu hukum serta meliha konsepkonsep Good Corporate Govermance yang terdapat dari berbagai literatur sehingga penelita akan menemukan ide-ide yang melahirkan pengertian-pengertian hukum, konsep-konsep hukum, dan asas-asas hukum yang relevan dengan isu yang dihadapi (Peter Mahmud Marzuki, 2009).

c. Pendekatan filosofis atau filsafat, pendekatan ini bukan bertujuan untuk menjawab dari permasalahan yang ada, tetapi lebih menuju ke menemukan permasalahan Karena sifat filsafat yang menyeluruh, mendasar dan spekulatif. Pendekatan filsafat ini akan lebih membentuk Fundamental Research, yaitu dalam penelitian ini akan lebih memperoleh pemahaman yang lebih terhadap implikasi sosial dan dampak dari penerapan suatu undang-undang terhadap masyarakat atau suatu kelompok masyarakat yang didalam penelitian berkaitan dengan sejarah, filsafat, ilmu bahasa, ekonomi dan juga implikasi sosial serta potik terhadap pemberlakuan suatu aturan hukum yang ada.

\section{Sumber Bahan Hukum}

Dalam penelitian ini peniliti menggunakan 3 jenis sumber bahan hukum, yaitu:

a. Bahan Hukum Primer

Bahan hukum primer merupakan bahan hukum yang bersifat autoritatif artinya mempunyai otoritas, dimana bahan hukum ini terdiri dari perundang-undangan, catatan-catatan resmi atau risalah dalam membuat 
perundang-undangan dan putusan-putusan hakim jika dibutuhkan (Peter Mahmud Marzuki, 2009).

b. Bahan Hukum Sekunder

Bahan hukum sekunder yaitu berupa semua publikasi tentang hukum yang bukan merupakan dokumendokumen resmi, biasanya berupa buku-buku hukum atau referensi-refensi, jurnal-jurnal, karya tulis ilmiah, internet bahkan juga surat media masa yang keseluruhannya terkait dengan isu hukum yang ada (Peter Mahmud Marzuki, 2009).

c. Bahan Hukum Tersier

Bahan hukum tersier juga merupakan bahan hukum yang juga harus dapat menjelaskan bahan hukum primer maupun bahan hukum sekunder. Bahan hukum ini dibutuhkan untuk menunjang bahan hukum lainnya.

\section{Metode Pengumpulan dan Pengolahan Bahan}

\section{Hukum}

Metode pengumpulan data pada penelitian ini dengan melakukan studi pustaka terhadap bahan-bahan hukum, baik bahan hukum primer, bahan sekunder mapun bahan hukum tersier. Studi kepustakaan dilakukan dengan cara menelaah, membaca, mencatat segala hal-hal yang berkaitan dengan isu hukum yang sedang dibahas selain itu juga membuat ulasan bahanbahan pustaka yang terkait. Metode pengumpulan bahan hukum ini juga dapat dilakukan dengan cara documenter, yaitu dikumpulkannya referensi dari berbagai sumber baik jurnal, makalah, penelitian, buku-buku, Koran, majalah, internet dll terkait segala hal yang berkaitan dengan isu hukum yang diangkat. Peneliti dalam hal ini menggunakan pendekatan perundang-undangan, hal pertama yang harus perlu dilakukan pula yaitu mencari dan mengumpulkan peraturan perundang-undangan mengenai atau yang berkaitan dengan isu hukum yang sedang di bahas (Peter Mahmud Marzuki, 2009). Selain itu wawancara juga dapat dilakukan, hal ini bertujuan untuk menunjang tknik dokumenter dan memperoleh bahan hukum untuk menjawab isu hukum yang terjadi.

Semua bahan hukum yang telah dikumpulkan tersebut kemudian diolah, dalam penlitian ini digunakan metode pengolahan dengan cara editing, yaitu dengan cara memeriksa kembali bahan-bahan hukum yang diperoleh baik dari segi kelengkapannya, kesesuaian, kejelasan, serta relevansinya dengan bahan hukum yang lain (Saifullah, 2004).

\section{Metode Analisis Bahan Hukum}

Peneliti dalam menganalisa bahan hukum yang ada dengan cara mengklasifikasikan bahan-bahan hukum yang ada agar mudah dianalisis dan dikonstruksikan. Dalam hal ini karena jenis penelitian berupa penelitian normatif maka maka sistem analisisnya dengan cara diskriptif kualitatif yang merupakan analisa data-data yang tidak bisa dihitung. Kemudian bahan hukum yang sudah diperoleh kemudian dikelompokkan, diperiksa dan kemudian dilakukan pembahasan. Setelah itu bahan hukum kemudian akan di interpretasikan dengan metode interprertasi sistematis, gramatikal dan teleologis (Asshiddiqie, 1996).

\section{HASIL DAN DISKUSI}

Persoalan mendasar yang harus diselesaikan dalam setiap sistem peradilan pidana adalah bagaimana mengatur bentuk diskresi tersebut dalam mekanisme penyelesaian perkara pidana di luar persidangan. Sebagai gambaran bagaimana Belanda dan Inggris yang telah lama mengembangkan model-model diskresi kewenangan penuntutannya guna dibandingkan dengan di Indonesia, berikut ini ditunjukan model-model diskresi kewenangan penuntutan di Belanda dan Inggris sebagai berikut:

\section{Belanda}

Belanda sebagai salah satu negara dengan tradisi European Civil Law dan menggunakan sistem penuntutan inquisitorial, memandang proses peradilan pidana sebagai proses yang harus dilakukan secara sah untuk menemukan kebenaran secara rasional dan tidak berpihak (Luna \& Wade, 2010). Oleh karena itu, Sistem hukum dipandang sebagai suatu instrumen rasional yang menerapkan metode ilmiah untuk menemukan kebenaran dan keadilan, sehingga hukum adalah science karena merupakan produk dari keputusan yang rasional yang dapat menghadirkan kebenaran dan memberikan keadilan melalui logika dan analisis yang seimbang (Luna \& Wade, 2010).

Konsekuensi sistem penuntutan inquisitorial yang dianutnya, maka penuntut umum di Belanda memiliki 
posisi kuat dan dominan dalam setiap tahap proses pidana (Crijns, 2011). Penuntut umum juga memiliki wewenang memerintahkan kepada polisi beberapa hal yang harus dilakukan dalam tahap penyidikan, dan penuntut umum juga berwenang untuk meneruskan atau tidak meneruskan kasus tersebut ke pengadilan (Crijns, 2011). Asas-asas yang menjadi dasar diskresi kewenangan penuntutan tersebut adalah asas expediency yakni penuntut umum dapat tidak meneruskan penuntutan suatu perkara ketika kesalahan pelaku tersebut masih termasuk tindak pidana minor dan apabila peradilan tetap dilanjutkan justru tidak dapat memenuhi kepentingan public (Luna \& Wade, 2010). Selain asas expediency, dasar dikresi penuntutan yang lain adalah asas oportunitas (opportuniteitsbeginsel), yang artinya penuntut umum tidak diwajibkan untuk selalu membawa suatu kasus ke pengadilan, ia juga boleh menyelesaikan suatu kasus atas kewenangannya sendiri atau memutuskan untuk menghentikan penuntutan kasus tersebut (Crijns, 2011).

Diskresi kewenangan penuntutan di Belanda diatur dalam hukum pidana materiil yakni Wetbook van Strafrecht (Sr) dan dalam hukum pidana formil yakni Wetbook van Strafvordering (Sv). Penuntut umum dapat menghentikan penuntutan dengan tanpa syarat tertentu (onvoorwardelijk sepot, Pasal 167 ayat (2) Sv. dan Pasal 242 ayat (2) Sv.), maupun dengan syarat tertentu (voorwardelijk sepot: Pasal 167 ayat (2) Sv., Pasal 257 a-h Sv. ). Sedangkan mekanisme penghentian penuntutan dengan syarat-syarat tertentu biasa dikenal dengan transaksi (Pasal 74- 74c Sr.). Lebih dari 30\% perkara pidana di Belanda diselesaikan dengan mekanisme transaksi ini (Kempen, 2009).

Di Belanda terdapat beberapa metode alternatif dari penuntutan yang bisa digunakan oleh penuntut umum, namun ada tiga metode yang sangat sering digunakan yakni non-prosecution, transaksi, dan penal order yang akan dibahas sebagai berikut :

\section{a. Non-prosecution}

Non Prosecution artinya penuntut umum dapat memutuskan tidak melakukan penuntutan dalam hal jika dilakukan penuntutan mungkin tidak menghasilkan adanya hukuman bagi terdakwa, baik karena kurangnya alat bukti atau alasan teknis lainnya (penghentian penuntutan karena alasan teknis atau prosedural) (Tak, 2006). Penuntut umum juga dapat tidak melakukan penuntutan berdasarkan asas kelayakan sebagaimana tercantum dalam Pasal 167 Sv. menentukan bahwa "penuntut umum harus memutuskan untuk melakukan penuntutan jika penuntutan dinilai penting berdasarkan hasil penyidikan. Penuntutan dapat dihentikan berdasarkan kepentingan publik"'(Tak, 2006).

Penuntut umum dapat menunda dilakukannya penuntutan secara bersyarat dalam kasus-kasus tertentu. Penundaan penuntutan terhadap suatu kasus tidak ada dasarnya dalam undang-undang di Belanda, oleh karena itu secara teoretis membingungkan, tapi secara umum penundaan penuntutan tersebut bisa diterima. Syarat-syarat umum atau syarat-syarat khusus dilakukannya penundaan penuntutan tidak pernah ada, tapi dalam praktek penuntut umum menggunakan syarat-syarat yang sama seperti syarat-syarat yang dipergunakan oleh hakim ketika menjatuhkan penundaan hukuman (Tak, 2006).

Broad of Prosecutors-General menerbitkan panduan penuntutan nasional untuk mengharmoniskan penggunaan diskresi kewenangan penuntutan tersebut. Seluruh penuntut umum di Belanda diperintahkan mengikuti panduan tersebut, kecuali ada situasi dan kondisi tertentu dalam suatu kasus tertentu. Berdasarkan panduan tersebut, penuntut umum dapat menghentikan penuntutan suatu kasus dengan pertimbangan kepentingan umum, jika antara lain sebagai berikut (Tak, 2003):

1) Dapat diyakini bahwa tindakan lain yang bukan sanksi pidana telah cukup untuk diterapkan atau akan lebih efektif (misalkan sanksi disiplin, administrasi, atau sanksi perdata lainnya).

2) Penuntutan terhadap tindak pidana itu dinilai tidak proporsional, tidak adil, atau tidak efektif terhadap kejahatan tersebut (misalkan kejahatan itu tidak menimbulkan bahaya dan tidak layak untuk menjatuhkan sanksi pidana terhadapnya).

3) Penuntutan terhadap tindak pidana itu dinilai tidak proporsional, tidak adil, atau tidak efektif dengan pertimbangan melihat kondisi pelakunya (misalkan kondisi usia dan kesehatan pelaku, prospek rehabilitasi, pelaku pertama kali).

4) Penuntutan tersebut bisa bertentangan dengan kepentingan negara, (misalkan dengan 
pertimbangan keamanan, kedamaian, dan ketertiban, atau jika penerapan hasil legislasi baru diperkenalkan).

5) Jika penuntutan dilakukan akan menjadi bertentangan dengan kepentingan korban (misalkan kompensasi atau ganti rugi telah dibayarkan).

Sedangkan penghentian penuntutan karena alasan teknis dapat disampaikan antara lain (Tak, 2003):

a) Kesalahan dalam registrasi tersangka oleh Kepolisian.

b) Kekurangan alat bukti untuk melakukan penuntutan.

c) Adanya larangan untuk adanya suatu penuntutan.

d) Pengadilan tidak memiliki kompetensi hukum untuk mengadili perkara ini.

e) Perbuatan tersebut tidak digolongkan sebagai tindak pidana dalam undang-undang.

f) Pelaku tidak harus bertanggungjawab secara pidana karena adanya alasan pembenar atau alasan pemaaf.

Isu selanjutnya, terkait siapa yang seharusnya berwenang merumuskan kebijakan penuntutan. Isu ini sangat penting dalam konteks hubungan antara Eksekutif dan Organ Penuntutan. Ashworth menyampaikan bahwa yang berwenang adalah pihak yang memerankan quasi-judicial yakni kewenangan penuntut umum untuk secara independen mengambil keputusannya (Tak, 2003).

\section{b. Transaction}

Sejarah lahirnya wet tot vereenvoudiging van de rechtspleging in lichte stafzaken (Undang-undang penyederhaan penyelenggaraan pemeriksaan pengadilan untuk kasus-kasus pidana ringan) tanggal 5 Juli 1921, Stb.883, menunjukan bahwa pada masa itu, pemerintah Belanda sedang mengalami persoalan dengan peningkatan perkara yang masuk untuk diproses di pengadilan, sehingga terbit ketentuan lama Pasal 74 Sr. (Pasal 82 KUHP) tentang transaksi, yang mensyaratkan bahwa dengan membayar denda maksimum maka terdakwa dapat terhindar dari tuntutan hukum (Remmelink, 2003). Pada tanggal 1 Mei 1983 kewenangan transaksi mengalami perluasan melalui Wet vermogenssancties (Undang-Undang Negara Belanda tentang Sanksi terhadap Harta Benda
Terpidana), sehingga jaksa/penuntut umum dapat menerapkan syarat-syarat sebagai imbalan penghentian penuntutan hukum tidak hanya untuk semua tindak pelanggaran, namun juga untuk kejahatan-kejahatan, terkecuali yang diancamkan pidana penjara lebih dari enam tahun (Remmelink, 2003).

Transaksi dapat dipahami sebagai salah satu bentuk diskresi kewenangan penuntutan yakni dengan cara jika terdakwa secara sukarela membayar sejumlah uang kepada kas negara atau memenuhi satu atau lebih persyaratan yang diajukan oleh penuntut umum dengan maksud menghindarkan penuntutan pidana lebih lanjut dan peradilan yang terbuka untuk umum (Tak, 2006). Diterimanya tawaran transaksi dari penuntut umum sebenarnya menguntungkan terdakwa, karena ia terhindar dari peradilan yang terbuka untuk umum, dan transaksi tidak dicatat oleh pengadilan dalam catatan kriminal, dan ia tidak lama dalam situasi ketidakpastian tentang hukuman yang akan diterimanya. Pada sisi lain, dengan menerima transaksi maka terdakwa melepaskan hak-haknya untuk dihukum berdasarkan pengadilan yang bebas yang dijamin oleh UndangUndang, (Pasal 6 European Concention of Human Rights / ECHR) (Tak, 2006).

Pasal 74 ayat (1) Sr. mewajibkan jaksa untuk melakukan penawaran transaksi sebelum dimulainya persidangan untuk perkara-perkara yang memenuhi syarat tertentu dapat diselesaikan melalui mekanisme transaksi atau afdoening buiten proces. Pasal 74 ayat (2) Sr. menguraikan syarat-syarat tertentu yang dapat diajukan oleh jaksa dalam penawaran transaksi tersebut. Pasal 74 ayat (3) Sr. menentukan kewajiban jaksa untuk menyampaikan informasi kepada pihak yang berkepentingan (kepada korban misalkan) tentang tanggal batas waktu dipenuhinya syarat-syarat transaksi tersebut.

Selanjutnya Pasal 74a Sr. menegaskan bahwa terdakwa memiliki hak untuk menghapuskan kewenangan penuntutan jaksa dengan membayar sejumlah denda dan syarat-syarat lain yang harus dipenuhi. Pasal 74b Sr, mengatur bahwa jika dalam waktu sebelum tiga bulan dari diterimanya kesepakatan transaksi oleh terdakwa, kemudian pengadilan memerintahkan agar dibuka kembali perkara itu untuk dilakukan proses penuntutan (misalkan atas dasar 
Zunaidi, etc.

pp. 1-15
E-ISSN : 2723-2476

P-ISSN : 2723-1968

ACLJ, Vol.1, Issue 1, 2020

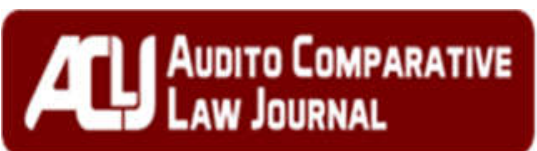

pengaduan korban), maka proses penuntutan harus dilaksanakan. Akan tetapi mekanisme ini hanya berlaku untuk kejahatan. Terakhir Pasal 74c Sr. memberikan kewenangan transaksi oleh polisi atau penyidik khusus lainnya dengan batasan-batasan tertentu.

Perlindungan hak warga negara untuk mendapatkan peradilan pidana yang cepat, sederhana, dan biaya ringan dalam praktek penegakan hukum pidana di Belanda, dapat dipenuhi antara lain dengan bekerjanya mekanisme afdoening buiten proces ini dengan cukup luas, sehingga untuk tindak-tindak pidana yang bersifat ringan mayoritas diselesaikan dengan mekanisme tersebut. Perlindungan hak warga negara untuk mendapatkan peradilan pidana yang cepat, sederhana, dan biaya ringan terwujud dengan jelas dari bunyi ketentuan Pasal 74 ayat (1) Sr. yang secara tegas menyebutkan bahwa jaksa/penuntut umum harus mengajukan penawaran sebelum dimulainya sidang perkara yang bersangkutan. Namun hal ini tidak sekaligus menutup kemungkinan tersangka yang melihat bahwa terhadapnya tidak diajukan transaksi, dapat mengajukan permohonan untuk itu terhadap jaksa/penuntut umum (Tak, 2006).

Persetujuan (consent) yang diberikan tersangka terhadap penawaran transaksi dari penuntut umum adalah bentuk informed consent karena tersangka telah memahami betul akibat atau dampak dari pilihannya untuk menerima atau menolak tawaran transaksi, dan tersangka juga berada pada posisi yang bebas memilih, tidak boleh ada paksaan atau tekanan dari penuntut umum. Dengan demikian, kritik terhadap mekanisme transaksi dari aspek asas praduga tidak bersalah menjadi sangat lemah dan tidak relevan lagi (Albrecht, 2001).

\section{c. Penal Order}

Berdasarkan amandemen terhadap Wetbook van Strafvordering / Sv. (KUHAP Belanda) yakni dengan menambahkannya Bab IVA, maka "prosecution through penal orders" yang diatur dalam Pasal 257 a h Sv. mulai berlaku pada tahun 2008. Selain itu, Pasal 12 Sv. juga diamandemen untuk membuka peluang pihak yang dirugikan agar bisa mengajukan keberatan kepada pengadilan banding dan meminta kasus dibuka
Kembali penuntutannya di pengadilan (BrantsLangeraar, 2007).

Penghentian penuntutan dengan syarat-syarat tertentu dan mekanisme transaksi akan dihapuskan. Tidak lagi mengarahkan pada tercapainya "kesepakatan", penuntut umum harus menyampaikan kepada tersangka satu atau beberapa "perintah pidana" (penal orders) atau OM afdoening door strafbeschikking, gambaran tindak pidananya, dan rencana usulan pembayaran denda. Sebelum melakukan hal tersebut, penuntut umum harus "membuktikan kesalahan" tersangka, walaupun pengakuan tersangka atas kesalahannya tidak penting. Denda lebih dari $€ 2.000$,- dan pengenaan pidana kerja sosial disampaikan penuntut umum kepada tersangka untuk mendengar tanggapannya (Brants-Langeraar, 2007).

Perintah dari penuntut umum tersebut memiliki status hukum sama seperti putusan oleh pengadilan (Kempen, 2009). Penuntut umum dapat mengajukan beberapa perintah berikut ini : kerja sosial (taakstraf) dengan maksimum 180 jam, denda (boete), pengasingan dari masyarakat (onttrekking aan het verkeer), pembayaran kepada negara untuk korban, dan pencabutan surat ijin mengemudi (ontzegging van de rijbevoegdheid). Penuntut umum tidak berwenang memerintahkan pidana penjara, sebagaimana ditentukan dalam Pasal 257a Sv (Kempen, 2009).

Tersangka dapat menolak perintah pidana dari penuntut umum tersebut, dengan mengajukan keberatan kepada pengadilan distrik, yang kemudian akan mendengar kasus tersebut secara keseluruhan; jika tersangka tidak mengajukan keberatan tersebut dalam waktu dua minggu, maka perintah tersebut dapat dilaksanakan secepatnya (Brants-Langeraar, 2007). Dengan diberikannya hak kepada tersangka untuk menerima atau menolak perintah pidana dari penuntut umum tersebut, maka dinyatakan bahwa hak tersangka untuk mendapatkan peradilan yang independen dan tidak memihak sebagaimana dimaksud dalam Pasal 6 ayat (1) European Convention of Human Rights (ECHR), telah dipenuhi (Jacobs \& Kampen, 2014).

Mekanisme Perintah pidana tersebut dapat diterbitkan untuk tindak pidana-tindak pidana yang sejenis dapat diselesaikan dengan mekanisme 
transaksi, dan syarat-syarat serta pidana yang diperintahkan dalam praktek juga bisa sama persis dengan syarat-syarat yang diajukan pada mekanisme transaksi (Jacobs \& Kampen, 2014). Penuntut umum sekarang memiliki satu tindakan baru yang dapat digunakan terhadap tersangka, yakni penyitaan Surat Ijin Mengemudi tersangka untuk waktu paling lama enam bulan, polisi juga dapat menerbitkan perintah pidana denda maksimum €225,- (Pasal 257 b Sv.) (Jacobs \& Kampen, 2014).

Dalam pembahasan di Parlemen rancangan amandemen Pasal 257 Sv. tersebut, Menteri Kehakiman Belanda (Minister of Justice) menyampaikan bahwa daripada menerapkan mekanisme plea bargaining, lebih tepat bila diperkenalkan sebuah sistem yang memberikan kewenangan kepada penuntut umum untuk mengenakan denda dalam bentuk perintah pidana (Jacobs \& Kampen, 2014). Mekanisme perintah pidana oleh penuntut umum tersebut akan mampu menangkap burung dengan satu batu : pengadilan menjadi tidak terbebani dan akan ada pemidanaan yang lebih riil. Lebih lanjut lagi, akan mampu memecahkan persoalan terdakwa yang telah menerima mekanisme transaksi tapi masih belum juga membayar (jumlahnya sekitar $25 \%)$; karena transaksi meskipun secara substantif adalah denda, tapi secara formal kesepakatan tersebut tunduk pada hukum sipil, ketidakpatuhan terhadap kesepakatan transaksi akan dipecahkan dengan penuntutan itu sendiri atau dengan melalui mekanisme hukum perdata yang rumit (Jacobs \& Kampen, 2014). Dengan adanya sistem baru tersebut, pengenaan tuntutan denda adalah bagian dari proses penuntutan, dan denda itu sendiri adalah sebuah sanksi pidana, artinya penuntut umum dapat melaksanakan denda itu secara langsung (Jacobs \& Kampen, 2014).

Mekanisme penal order juga tidak sempurna, banyak kritik yang disampaikan oleh para ahli. Dalam mekanisme penal order tidak dikenal adanya negosiasi sebelum diterbitkannya perintah tersebut, sehingga posisi tersangka adalah terjepit harus memilih menerima perintah tersebut atau menjalani proses persidangan. Dengan menerima perintah pidana tersebut, dapat diasumsikan tersangka telah bersalah, sedangkan jika memilih proses persidangan yang rumit dan lambat maka ia harus melawan rasa malu dan stigma negatif dari proses peradilan pidana. Oleh karena itu, mekanisme penal order sedikit banyak telah bertentangan dengan asas praduga tak bersalah atau presumption of innocent (Jacobs \& Kampen, 2014).

Selain itu, dengan diberikannya kewenangan penuntut umum untuk mengeluarkan perintah pidana, maka akan terbentuk suatu badan penuntut umum yang memiliki kewenangan penuntutan, "mengadili", dan pelaksanaan pemidanaan, seperti pada sistem peradilan pidana masa lampau yang telah lama hilang. Oleh karenanya, tidak ada kontrol external judisial yang mengatur situasi ketika perintah pidana tersebut dilaksanakan (Jacobs \& Kampen, 2014). Selain itu, semakin berat pula beban penuntut umum untuk bertindak jujur, transparan, tidak memihak.

Menurut J. F. Nijboer, manfaat yang dapat dirasakan oleh negara Belanda, yang menerapkan mekanisme transaksi atau afdoening buiten proces secara meluas dalam hukum acara pidananya, sehingga hukum pidana seringkali dipandang dan digunakan sesuai asas subsidiaritas - hukum pidana sebagai ultimum remedium, adalah sebagai berikut :

1. Semakin berkurangnya perkara yang masuk dalam sistem peradilan pidana.

2. Menurunnya frekuensi penggunaan pidana penjara.

3. Lebih pendeknya masa pidana penjara, yang mencerminkan adanya kebijakan pemidanaan yang berbeda atau praktek yang berbeda dari negara lain terkait pembebasan terpidana sebelum masa pemidanaan selesai.(Nijboer, 1999)

Hasil akhir dari semakin berkurangnya perkara yang masuk dalam sistem peradilan pidana, menurunnya frekuensi penggunaan pidana penjara, dan diperpendeknya masa pidana penjara adalah semakin berkurangnya penghuni penjara di Belanda. Hal itu merupakan fakta yang kontras dengan apa yang terjadi negara-negara Eropa lainnya. D. Downes mempublikasikan hasil penelitian yang sangat menarik pada tahun 1988, yang membandingkan kebijakan pidana di Inggris dan Wales di satu sisi dengan di Belanda pada sisi lain (Nijboer, 1999). Berdasarkan data yang dipublikasikan Downes tersebut, terdapat perbedaan yang menyolok dalam angka rata-rata penggunaan pidana penjara antar negara-negara 
Zunaidi, etc.

pp. 1-15
E-ISSN : 2723-2476

P-ISSN : 2723-1968

ACLJ, Vol.1, Issue 1, 2020

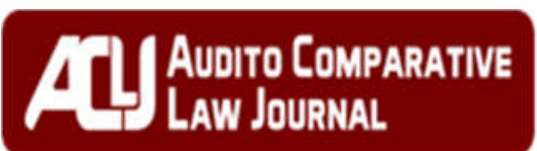

tersebut. Perbedaan tersebut semakin menyolok, dengan melihat pertentangan latar belakang yang pararel dengan meningkatnya angka kejahatan di kedua negara tersebut, artinya meskipun di Belanda angka kejahatan yang dilaporkan meningkat, hal yang sama juga terjadi di Inggris dan Wales, namun persentase perbandingan jumlah penghuni penjara dengan jumlah penduduk di Belanda tidak mengalami kenaikan secara signifikan (Nijboer, 1999).

Sedangkan di Inggris dan Wales, persentase perbandingan jumlah penghuni penjara dengan jumlah penduduk juga mengalami kenaikan secara signifikan seiring meningkatnya angka kejahatan yang dilaporkan. Meskipun terdapat beberapa indikasi yang menunjukan menurunnya kebijakan toleransi pemerintah Belanda terhadap kejahatan, namun negara ini tetap dinilai sebagai satu-satunya negara yang paling lembut reaksinya terhadap fenomena sosial yang disebut dengan kriminalitas (Nijboer, 1999).

Berdasarkan uraian kebijakan pengaturan diskresi kewenangan penuntutan di Belanda tersebut, maka terlihat adanya konsistensi tujuan sistem penuntutan inquisitorial yakni untuk menemukan kebenaran dan memberikan keadilan secara rasional, logis, dan analisis yang seimbang, dengan hasilnya yakni jaminan kelayakan penuntutan dan pidana yang dijatuhkan terhadap pelaku dan tindak pidananya, bukan hanya memaksimalkan jumlah pemidanaan, dan kenyataan semakin bertambahnya beban penanganan perkara dan keterbatasan sistem peradilan pidana, baik kurangnya sumberdaya manusia maupun anggaran negara. Oleh karena itu, pengaturan diskresi kewenangan penuntutan di Belanda memberikan kesempatan bagi penuntut umum untuk memutuskan secara rasional, logis, dan analisis yang seimbang dalam setiap perkara yang ditangani melalui beragam bentuk pilihan metode penuntutan (non prosecution, transaction, atau penal order) yang sesuai asas kelayakan baik terhadap pelaku maupun tindak pidananya. Kondisi yang berbeda terjadi di Indonesia yang masih sangat kaku, baik pada level peraturan perundang-undangan ataupun kebijakan penuntutan yang masih mengejar jumlah penanganan perkara dan rata-rata pemidanaan, yang justru dampaknya semakin membebani sistem peradilan pidana.
Berdasarkan rangkaian perubahan pertimbangan kebijakan pidana di Belanda berupa non prosecution, transaction dalam Pasal $74 \mathrm{Sr}$. dan dalam wet vermogensancties (undang-undang tentang Sanksi Terhadap Harta Benda), dan penal order dalam revisi Wet Book van Strafvordering sehingga menghasilkan Pasal 257 a - h Sv. tersebut, maka telah terlihat ratio legis pengaturan penyelesaian perkara pidana di luar persidangan adalah untuk mewujudkan keadilan melalui penyederhanaan proses peradilan pidana dengan menerapkan asas kelayakan yakni penuntut umum harus memperhatikan faktor kepentingan publik dalam memutuskan untuk melakukan penuntutan dan memilih mekanisme penuntutan yang layak dengan kesalahan pelaku.

Manfaat penerapan asas kelayakan berupa penyederhanaan sistem peradilan pidana tersebut adalah menjadi lebih efektifnya sistem peradilan pidana. Penyederhanaan sistem peradilan pidana sangat dibutuhkan dalam keadaan munculnya berbagai persoalan terkait peningkatan jumlah dan kualitas perkara yang masuk untuk diproses di pengadilan, sehingga pengadilan tidak terbebani dengan perkaraperkara minor dan tetap ada pemidanaan yang riil dan layak dengan kesalahan dalam tindak pidana minor, dan sumber daya penegak hukum dapat lebih difokuskan untuk penanganan perkara-perkara yang lebih berat.

\section{Inggris dan Wales}

Berbeda dari Belanda dengan sistem penuntutan inquisitorial, Inggris dan Wales adalah negara-negara dengan sistem penuntutan adversarial sebagaimana dalam tradisi hukum common law yang menerima asas kelayakan dan asas oportunitas sehingga dasar pelaksanaan diskresi kewenangan penuntutan tidak hanya diberikan kepada penuntut umum ataupun pejabat seniornya, tetapi konsisten di dalam sistem hukumnya. Bahkan keputusan untuk melakukan atau tidak melakukan penuntutan, tidak secara eksklusif menjadi tanggungjawab penuntut umum. Banyak sekali keputusan untuk tidak melakukan penuntutan diambil oleh polisi sehingga sulit dilakukan kontrol pengawasannya. Polisi diberikan kewenangan untuk tidak melakukan tindakan lebih lanjut, memberikan peringatan informal, atau peringatan yang tercatat 
tanpa harus memberitahukannya kepada CPS (Crown Prosecution Service)(Kyprianou, n.d.).

Konsistensi diskresi kewenangan penuntutan dalam sistem hukum di Inggris dapat dilihat pada sejarah sistem penuntutan di Inggirs. Inggris awalnya tidak memiliki lembaga yang khusus berfungsi melakukan penuntutan, penuntutan juga dapat dilakukan oleh individu personal atau privat, sehingga menimbulkan persoalan efisiensi dan kesulitan pembuktian kesalahan dan pemidanaan pelaku, dan seringkali memancing hakim untuk aktif bertindak seperti penuntut umum yang melanggar prinsip judicial impartiality (Summers, 2007).

Berdasarkan Marian Statutes 1555 dibentuk Justices of the Peace (JPs) sebagai penuntut umum, yang dipilih oleh Royal Commission untuk setiap daerah dan setiap kota dengan tugas melakukan penegakkan hukum terhadap kejahatan di Inggris (Langbein, 1973). Setiap individu JPs juga memiliki tanggungjawab yang sangat penting dalam proses penghentian penyelesaian perkara pidana di luar persidangan, untuk memerintahkan penahanan tersangka, melakukan penuntutan sampai ke persidangan, dan melakukan pembebasan tersangka yang ditahan berdasarkan penundaan persidangan atas jaminan (Langbein, 1973).

Selain itu, Polisi juga bertanggungjawab terhadap penuntutan suatu perkara yang dapat dilakukannya dengan menunjuk beberapa pengacara lokal yang berpengalaman, sehingga tidak ada keseragaman dan kepastian pengawasan kebijakan penuntutan secara nasional (Langer et al., 2016). Baru pada Oktober 1986, Crown Prosecution Service melaksanakan fungsinya untuk melakukan penuntutan di Inggris, sebagai reaksi terhadap rangkaian tindakan oleh Polisi yang mencederai keadilan dalam manipulasi bukti-bukti dan penekanan oleh Polisi, sehingga apabila Polisi akan melakukan penuntutan maka harus diuji dulu oleh CPS, sebagaimana diatur dalam Pasal 23 ayat (8) Prosecution of Offences Act Tahun 1985 (Luna \& Wade, 2010).

Attorney General dapat menghentikan proses penuntutan yang sedang berjalan yang biasanya diinisiasi oleh pihak pribadi atau privat apabila penuntutan tersebut dinilai bertentangan dengan kepentingan kerajaan dan tidak terlalu penting (Krauss,
2012). Kewenangan Attorney General untuk menghentikan penuntutan yang sedang berjalan tersebut merupakan instrumen prosedural yang tidak dapat diuji oleh pengadilan berdasarkan teori the separation of prosecutorial powers bahwa eksekutif memiliki wewenang kontrol terhadap penanganan perkara dan berdasarkan kondisi faktual semakin beratnya beban sistem peradilan pidana sehingga penuntut umum harus memprioritaskan penuntutan antara beberapa perkara (Tak, 2006).

Oleh karena itu, sistem penuntutan di Inggris menarik untuk dicermati. Tidak seperti sistem penuntutan di negara-negara Eropa Barat lainnya, Crown Prosecution Service berada pada posisi yang lebih lemah dibandingkan dengan Kepolisian, dalam hal penggunaan diskresi kewenangan penuntutan untuk menyelesaikan perkara di luar pengadilan. Padahal sesungguhnya berdasarkan tradisi common law, sistem penuntutan di Inggris dan Wales memberikan ruang yang luas bagi penerapan diskresi kewenangan penuntutan untuk dihentikannya penuntutan suatu kasus dengan alasan kepentingan publik.

Diskresi kewenangan penuntutan diatur melalui mekanisme penyelesaian perkara pidana di luar persidangan melalui mekanisme cautioning, reprimands and warning, dan deferred prosecution agreements berikut ini :

\section{a. Mekanisme cautioning dan reprimands and warning}

Penuntut umum di Inggris, berwenang menghentikan penuntutan suatu kasus dengan pertimbangan kepentingan publik, tapi penelitian menunjukan bahwa penuntut umum kurang sukses dalam melaksanakan diskresi kewenangannya tersebut. M. Mc Conville, A. Sanders dan Leng (Kyprianou, n.d.), menemukan bahwa CPS jarang menghentikan penuntutan dengan dasar kepentingan publik, tapi saat ini, penghentian penuntutan oleh CPS mulai meningkat, namun seringkali dilakukan untuk kasus yang tidak penting dan sering juga didasarkan atas penghitungan biaya. Hal itu terjadi karena kontrol polisi atas informasi dan konstruksi kasusnya dibangun menjadi benar-benar sulit bagi penuntut umum untuk mengidentifikasi kasus-kasus yang dapat diberikan peringatan saja 
(Kyprianou, n.d.). Beberapa faktor yang dapat ditunjuk sebagai dasar diberikannya peringatan atau tindakan lain pengganti tidak dilakukannya penuntutan lebih lanjut seringkali dihapuskan dalam file, atau fakta-fakta tersebut tidak ditunjukan oleh polisi karena gagalnya memberikan pertanyaan-pertanyaan yang relevan dalam tahap penyidikan (McConville et al., 1996).

Berdasarkan Pasal 23 Criminal Justice Act tahun 2003, syarat-syarat dan kriteria untuk dapat dilaksanakannya diskresi kewenangan penuntutan untuk menuntut atau tidak melakukan penuntutan telah dimodifikasi yakni:

1) Penegak hukum (jaksa dan polisi) memiliki buktibukti bahwa pelaku telah melakukan tindak pidana.

2) Adanya keyakinan penuntut umum bahwa terdapat cukup bukti untuk menuntut terdakwa karena melakukan tindak pidana dan peringatan bersyarat sebelumnya telah diberikan kepada terdakwa terkait tindak pidana yang dilakukannya.

3) Pelaku telah mengakui kepada polisi atau jaksa bahwa ia telah melakukan tindak pidana.

4) Penegak hukum (polisi dan jaksa) sebelumnya telah menjelaskan pengaruh peringatan bersyaratnya kepada pelaku dan memperingatkan pelaku tentang akibat gagalnya untuk memenuhi segala persyaratan yang dilampirkan dalam peringatan adalah bisa membawa dilakukannya penuntutan terhadap tindak pidananya.

5) Pelaku menandatangani dokumen peringatan yang berisi :
a. Detail tindak pidananya.
b. Pengakuan oleh pelaku bahwa ia telah melakukan tindak pidana tersebut.
c. Pelaku setuju untuk diberikan peringatan bersyarat tersebut, dan
d. Rincian syarat-syarat yang dilampirkan dalam peringatan tersebut.

Syarat-syarat tersebut adalah untuk menjamin bahwa pelaku benar-benar telah bersalah dan pasti akan dihukum jika dilakukan penuntutan, karena surat peringatan tersebut sebenarnya adalah pengakuan bersalah (yang bisa dicatat oleh pengadilan). Mekanisme peringatan ini dipergunakan oleh polisi untuk menyelesaikan hampir 30\% dari seluruh kasus yang dilaporkan kepada polisi (Tak, 2006).

$\mathrm{Di}$ Inggris, untuk mengatur penggunaan penyelesaian perkara di luar persidangan, maka Pemerintah Inggris telah menerbitkan Code for Crown
Prosecutors tahun 2000 berdasarkan Pasal 10 the Prosecution of Offences Act (POA) tahun 1985. Code for Crown Prosecutors tersebut menentukan bahwa sebelum melakukan penuntutan, ada dua syarat yang harus dipenuhi yakni terpenuhinya tes pembuktian (the evidential test) sehingga ada prospek keyakinan terbuktinya dakwaan tersebut secara realistis (realistic prospect of conviction), serta penuntutan tersebut hanya boleh dilakukan jika kepentingan publik menghendaki (the public interest test).

Syarat tes kepentingan publik tersebut meliputi tingat kesalahan pelaku (peran dalam keturutsertaan, adanya perencanaan), keadaan bahaya pada korban, dampaknya pada masyarakat. Selain itu, penuntut umum harus memperhatikan apakah penuntutan adalah respon yang layak bagi tindak pidana tersebut yakni penuntutan yang akan dilakukan harus sesuai dengan cara-cara yang konsisten dengan prinsip-prinsip penanganan perkara yang efektif.

Kriteria-kriteria lain untuk dapat diterapkannya mekanisme penyelesaian perkara di luar persidangan adalah berdasarkan the Crime and Disorder Act tahun 1998, yakni polisi dapat menghentikan proses hukum acara pidana lebih lanjut dengan menerbitkan Surat "Peringatan" (cautioning) terhadap pelaku dewasa, dan Surat "Teguran dan Peringatan" (reprimands and warning) terhadap pelaku remaja. "Peringatan" terhadap pelaku dewasa tersebut diberikan oleh polisi jika telah ada bukti yang cukup sebagai dasar dilakukannya penuntutan, pelaku mengakui kesalahannya, dan pelaku menyetujui prosedur yang ditetapkan. Selain itu pelakunya juga harus orang yang sudah cukup tua atau lemah, sakit mental, menderita beberapa penyakit fisik, atau menderita beberapa penyakit mental.

\section{b. Deffered Prosecution Agreements (DPA)}

Berdasarkan Crimes \& Court Act tahun 2013 yang berlaku sejak Februari 2014, maka penuntut umum dapat menerapkan mekanisme Deffered Prosecution Agreements (DPA) untuk menyelesaikan perkara suap, korupsi (cheating the public revenue), fraud, dan tindak pidana ekonomi lainnya yang dilakukan oleh korporasi atau badan hukum privat, karena mekanisme DPA ini tidak dapat diterapkan kepada subyek hukum orang (natural person). Crown Prosecution Service 
(CPS) dan Serious Fraud Office (SFO) menerbitkan DPA Code of Practise sebagai pedoman bagi penuntut umum untuk melaksanakan mekanisme DPA tersebut, yang pada intinya bahwa semua sanksi keuangan yang diajukan oleh penuntut umum dalam DPA harus benarbenar dapat diperkirakan sebanding dengan sanksi yang akan dijatuhkan oleh hakim saat terdakwa mengakui kesalahannya (court conviction guilty plea), bukan sanksi yang akan dijatuhkan oleh hakim pada terdakwa ketika ia kalah dalam pembuktian (court conviction contested trial).

Kesepakatan dalam DPA dapat tercapai antara penuntut umum dan badan hukum (korporasi) sehingga penuntut umum dapat menunda proses penuntutan dalam waktu tertentu sampai badan hukum tersebut mampu memenuhi sejumlah persyaratan seperti penyerahan keuntungan illegal, membayar denda, ganti rugi, dan biaya-biaya, bekerjasama dalam penuntutan terhadap orang pribadi yang terlibat, implementasi program-program kepatuhan perusahaan pada peraturan yang dilaksanakan dalam pengawasan penuntut umum. Kesepakatan yang tercapai antara penuntut umum dengan badan hukum tersebut harus mendapatkan persetujuan oleh hakim.

Mekanisme DPA memberikan fungsi checks and balances yang tepat kepada hakim pada tahap persiapan pembahasan dan hasil akhir kesepakatan dalam DPA tersebut (Organisation for Economic Cooperation and Development (OECD), 2017). Persetujuan oleh hakim tersebut dibutuhkan untuk menguji terpenuhinya kepentingan publik dalam kesepakatan DPA tersebut, dan sanksi pidana yang disepakati dalam DPA benar-benar telah proporsional dengan kesalahan badan hukum (Organisation for Economic Cooperation and Development (OECD), 2017).

Asas kelayakan muncul dalam norma Pasal 45 Schedule 17 part 1, angka 7 dan 8 Crimes \& Court Act tahun 2013 dan menjadi pedoman bagi hakim yang menilai poin-poin kesepakatan antara penuntut umum dan badan hukum yakni terpenuhinya kepentingan publik dalam kesepekatan DPA tersebut untuk mewujudkan keadilan. Asas kelayakan juga muncul dalam Deferred Prosecution Agreements Code of Practice yang diterbitkan oleh CPS dan SFO, yakni keharusan bagi Penuntut umum untuk benar-benar memperhatikan kepentingan publik (public interest test), selain terpenuhinya alat bukti kesalahan badan hukum (evidential test), dalam memutuskan untuk menerapkan mekanisme DPA tersebut.

Manfaat yang dapat dirasakan karena menerapkan mekanisme DPA tersebut adalah terhindarnya dari proses persidangan pidana yang lama dan tidak pasti hasilnya, biaya mahal, dan rumit, dan juga sebagai imbalan kepada perusahaan karena melaporkan sendiri tindak pidana tersebut sehingga perusahaan terhindar dari kerugian-kerugian yang timbul secara tidak disengaja seperti hancurnya harga saham yang berdampak pada pekerja yang tidak bersalah, investor, pensiunan, dan pelanggan. Kelemahan penggunaan mekanisme DPA tersebut adalah lemahnya pengawasan terhadap proses pengungkapan fakta-fakta secara menyeluruh karena awal penyelidikan perkara ini sering dimulai dari perusahaan sendiri yang melaporkan, sehingga rentan terhadap tindakan disembunyikannya fakta-fakta tertentu yang relevan (Dunn, n.d.).

Pada tahun 2013, dalam konteks tindak pidana dengan pelaku orang (nature person), perlindungan hak korban seperti hak mendapatkan pemulihan dampak tindak pidana atau ganti rugi dan hak meminta dibukanya kembali penghentian penuntutan oleh penuntut umum telah dinyatakan berlaku (Novokmet, 2016). Perlindungan hak korban untuk meminta dibukanya kembali penuntutan tersebut dinyatakan berlaku dalam pernyataan putusan Pengadilan Banding dalam kasus R v Christopher Killick (2011), EWCA Crim 1608, yang menyatakan bahwa keputusan untuk tidak melakukan penuntutan dalam kenyataannya merupakan hak korban. Pada level internasional, terdapat Pasal 11 Directive 2012/29/EU dari Parlemen Eropa dan Konsul Eropa tanggal 25 Oktober 2012 yang dengan tegas melindungi hak korban untuk meninjau ulang keputusan dihentikannya penuntutan suatu perkara (Novokmet, 2016).

Selain ketentuan Pasal 11 Directive 2012/29/EU, terdapat juga ketentuan Pasal 14 ayat (1) ICCPR yang menegaskan bahwa setiap orang wajib sama di hadapan pengadilan, dalam penentuan sanksi pidana terhadapnya, atau hak-hak dan kewajiban-kewajibanya 
Zunaidi, etc.

pp. 1-15
E-ISSN : 2723-2476

P-ISSN : 2723-1968

ACLJ, Vol.1, Issue 1, 2020

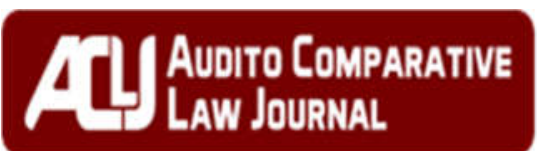

harus berdasarkan hukum, setiap orang harus mendapatkan peradilan yang fair, terbuka untuk umum, independen, dan tidak memihak berdasarkan hukum. Perlindungan hak korban untuk meminta dibukanya kembali penuntutan kepada hakim merupakan bentuk perwujudan prinsip fair trial karena hak untuk mendapatkan proses persidangan yang adil (fair trial) bukan absolut menjadi hak tersangka namun juga hak setiap warga negara, korban, dan saksi-saksi(Brants \& Franken, 2009).

Berdasarkan Pasal 14 ayat (1) ICCPR, pertimbangan putusan Pengadilan Banding dalam kasus $\mathrm{R} \mathrm{V}$ Christopher Killick (2011), Pasal 11 Directive 2012/29/EU, dan Pasal 45 Schedule 17 Crimes \& Court Act tahun 2013 tersebut, maka semua mekanisme penyelesaian perkara pidana di luar persidangan yang berlaku di Inggris dan Wales dapat dinilai tidak bertentangan dengan prinsip fair trial. Semua mekanisme penyelesaian perkara pidana di luar persidangan tersebut tetap menjamin kebebasan semua pihak (tersangka, korban, masyarakat, dan penuntut umum) untuk memilih langkah-langkah terbaik bagi kepentingan mereka dalam suatu sistem peradilan pidana.

Sejarah sistem penuntutan di Inggris dan Wales memperlihatkan bahwa mekanisme penyelesaian perkara pidana di luar persidangan telah melekat dalam sistem hukumnya melalui praktek-praktek penanganan setiap perkara dan telah berkembang atau disempurnakan melalui pengaturannya dengan beberapa undang-undang seperti Marian Statutes tahun 1555, Prosecution of Offences Act tahun 1985, Criminal Justice Act tahun 2003, Crimes \& Court Act tahun 2013, Code for Crown Prosecutors 2013, Deferred Prosecution Agreements Code of Practice 2013.

Berdasarkan rangkaian perubahan pertimbangan kebijakan pidana mekanisme penyelesaian perkara pidana di luar persidangan tersebut, maka terlihat ratio legis pengaturan penyelesaian perkara pidana di luar persidangan adalah untuk mewujudkan keadilan melalui penyederhanaan sistem peradilan pidana dan penerapan asas kelayakan yakni keharusan bagi Penuntut umum untuk benar-benar memperhatikan kepentingan publik (public interest test) dalam memutuskan menerapkan mekanisme penyelesaian perkara pidana di luar persidangan sehingga sumber daya penegak hukum dapat lebih difokuskan untuk penanganan perkara-perkara yang lebih berat.

\section{Indonesia}

Indonesia sebagai negara yang pernah mengalami masa penjajahan oleh Belanda, sebagai konsekuensi asas konkordansi maka sistem hukum yang berlaku di Indonesia saat ini sebagian besar masih merupakan warisan negara Belanda, termasuk sistem penuntutannya. Sama seperti Belanda, sistem hukum Indonesia juga dapat digolongkan sebagai mengikuti tradisi civil law dan dengan sistem penuntutan inquisitorial. Oleh karena itu, sistem hukum Indonesia mengikuti filosofi penuntutan mandatori, yang biasa dikenal implementasinya dengan asas legalitas. Dengan demikian, diskresi kewenangan penuntutan dalam sistem hukum Indonesia yang menganut asas legalitas adalah sebuah pengecualian dari aturan umum berdasarkan asas legalitas, maka keputusan untuk tidak melakukan penuntutan relatif dilakukan dengan kontrol yang sangat ketat jika dibandingkan dengan negaranegara yang mengikuti tradisi common law seperti Amerika, Inggris dan Wales.

Pengaturan kewenangan penuntutan di Indonesia dapat ditemukan pada Pasal 1 angka 6 huruf a. UndangUndang Nomor 8 Tahun 1981 tentang Hukum Acara Pidana (KUHAP) yang menyebutkan jaksa adalah pejabat yang diberi wewenang oleh undang-undang ini untuk bertindak sebagai penuntut umum serta melaksanakan putusan pengadilan yang telah memperoleh kekuatan hukum tetap. Kemudian Pasal 1 angka 6 huruf b. KUHAP menyebutkan Penuntut Umum adalah jaksa yang diberi wewenang oleh undang-undang ini untuk melakukan penuntutan dan melaksanakan penetapan hakim. Norma Pasal 1 angka 6 huruf b. KUHAP tersebut sama persis (terjadi duplikasi) dengan Pasal 13 KUHAP.

Selanjutnya dalam Pasal 14 KUHAP tentang kewenangan penuntut umum pada poin $g$ dan $h$ disebutkan bahwa penuntut umum berwenang melakukan penuntutan dan menutup perkara demi kepentingan hukum. Sedangkan dalam Pasal 140 ayat (2) huruf a. menyebutkan bahwa dalam hal penuntut umum memutuskan untuk menghentikan penuntutan 
karena tidak terdapat cukup bukti atau peristiwa tersebut ternyata bukan merupakan tindak pidana atau perkara ditutup demi hukum, penuntut umum menuangkan hal tersebut dalam surat ketetapan.

Diskresi kewenangan penuntutan baru dapat ditemukan dalam Pasal 35 huruf c. Undang-Undang RI Nomor 16 Tahun 2004 tentang Kejaksaan, yang memberikan kewenangan kepada Jaksa Agung untuk menghentikan suatu perkara atas dasar kepentigan umum (asas opportunitas). Dari semua ketentuan penuntutan dalam KUHAP maupun dalam Undangundang lainnya, telah jelas bahwa jaksa/penuntut umum saat ini tidak memiliki diskresi kewenangan untuk menghentikan ataupun mengenyampingkan perkara karena perkara tindak pidana tersebut bersifat ringan.

Jorg-Martin Jehle menjelaskan sebagai berikut :

... in accordance with strict principle of legality the prosecuting authority merely has the function of preparing a case for court. Here the input is identical to the out put; all cases have to be brought before a court ( - except evidentially insufficient cases etc. Which can, of course, be dropped in accordance with the principle of legality)(Jehle, 2005).

Penulis sependapat dengan Jorg-Martin Jehle tentang batasan dan pengertian ruang lingkup asas legalitas dengan asas oportunitas, bahwa suatu kasus tindak pidana yang dihentikan karena kurangnya alat bukti, terdakwa meninggal dunia, mematuhi asas ne bis in idem, dan karena kedaluarsa adalah alasan penghentian penuntutan yang dilakukan masih dalam kerangka asas legalitas atau masih sesuai dengan asas legalitas. Sedangkan penghentian penuntutan suatu kasus tindak pidana yang didasarkan pada asas oportunitas adalah penghentian suatu kasus tindak pidana berdasarkan asas kelayakan atau expedience principle yang menjadikan kepentingan umum sebagai pertimbangan utama (reason of public interest) dan berdasarkan teori subsosialitas (Pasal 9a Sr.) yakni kecilnya arti suatu perbuatan yang dapat dilihat dari tingkat kerugian, kerusakan, bahaya atau tercelanya suatu perbuatan pidana dan perilaku pelaku, serta kondisi-kondisi pada waktu tindak pidana dilakukan, dijadikan suatu ukuran patut tidaknya suatu perbuatan tersebut untuk dipidana.

\section{KESIMPULAN}

Ciri dianutnya asas legalitas secara kaku dapat kita temukan di Indonesia yakni penuntut umum hanya berwenang untuk melaksanakan fungsi menyiapkan perkara untuk disidangkan di pengadilan, sehingga input dan output dalam sistem peradilan pidana adalah identik, karena semua perkara harus dibawa ke depan persidangan (kecuali kasus tersebut tidak cukup bukti, atau perkara itu harus ditutup demi hukum yakni alasan kedaluarsa, ne bis in idem, dan terdakwa telah meninggal dunia), sebagaimana disebutkan dalam Pasal 14 huruf h KUHAP dan Pasal 140 ayat (2) huruf a KUHAP. Diskresi kewenangan penuntutan yang terwujud dalam Pasal 35 huruf c Undang-Undang Nomor 16 Tahun 2004 tentang Kejaksaan yang berbunyi: "Jaksa Agung mempunyai tugas dan wewenang mengesampingkan perkara demi kepentingan umum" tersebut, hanyalah implementasi asas oportunitas secara negatif.

Rumusan Pasal 35 huruf c tersebut memperlihatkan adanya kewenangan Jaksa Agung untuk mengesampingkan perkara sebagai implementasi asas oportunitas yang diterima dalam hukum acara pidana Indonesia, namun asas oportunitas tersebut terwujud secara negatif karena pengaturannya sangat dibatasi hanya Jaksa Agung saja yang boleh mengesampingkan perkara dengan alasan "kepentingan umum". Selain itu, pertimbangan subsosialitas juga belum diadopsi dalam hukum pidana kita.

Implementasi asas oportunitas secara negatif juga dapat dilihat dalam Pasal 82 KUHP yang mengatur tentang mekanisme transaksi di Indonesia yakni kewenangan menuntut pelanggaran yang diancam dengan pidana denda saja menjadi hapus, kalau dengan sukarela dibayar maksimum denda dan biaya-biaya yang telah dikeluarkan jika penuntutan telah dimulai, atas kuasa pejabat yang ditunjuk untuk itu oleh aturanaturan umum, dan dalam waktu yang ditetapkan olehnya. Apabila disamping pidana denda ditentukan perampasan, maka barang yang dikenai perampasan harus diserahkan pula, atau harganya harus dibayar menurut taksiran pejabat yang ditunjuk.

Selain itu, dalam Pasal 113 Undang-Undang Nomor 10 Tahun 1995 tentang Kepabeanan, pada ayat (1) menyebutkan bahwa untuk kepentingan penerimaan 
negara, atas permintaan Menteri, Jaksa Agung dapat menghentikan penyidikan tindak pidana di bidang kepabeanan. Kemudian pada ayat (2) disebutkan bahwa penghentikan penyidikan tersebut jika yang bersangkutan telah melunasi bea masuk yang tidak atau kurang bayar, dan membayar denda sebagai sanksi administrasi yang besarnya empat kali jumlah bea masuk yang tidak atau kurang dibayar.

Menurut pendapat penulis, kewenangan penghentian penyidikan ini oleh Jaksa Agung merupakan salah satu bentuk transaksi selain dari Pasal 82 KUHP, yang dilaksanakan atas dasar asas oportunitas. Namun sekali lagi terwujud dalam bentuk negatif karena harus dilakukan berdasarkan permintaan Menteri Keuangan, dan hanya Jaksa Agung yang berwenang bukanlah setiap personil jaksa.

Ketentuan dalam Pasal 82 KUHP tersebut menunjukkan dengan jelas bahwa mekanisme afdoening buiten proces atau transaksi yang diatur dalam Pasal 82 KUHP ini masih sepadan dengan Pasal 74 Sr., yakni penerapannya masih terbatas pada pelanggaran yang diancam pidana denda. Oleh karena itu, berdasarkan ketentuan Pasal 82 KUHP, mekanisme transaksi ini tidak bisa dilakukan terhadap tindak pidana yang bersifat ringan atau kejahatan kecil atau yang ringan akibatnya.

Sebagai penutup bagian ini, dapat disimpulkan bahwa berdasarkan analisis pertimbangan kebijakan pengembangan mekanisme penyelesaian perkara pidana di luar persidangan di Belanda dan Inggris tersebut, maka terlihat ratio legis pengaturan penyelesaian perkara pidana di luar persidangan adalah untuk mewujudkan keadilan melalui penyederhanaan sistem peradilan pidana dan penerapan asas kelayakan. Keadaan berbeda terjadi pada sistem peradilan pidana Indonesia karena sangat tidak efisien, tidak sesuai dengan asas peradilan cepat, sederhana, dan biaya ringan. Solusi atas persoalan tersebut adalah penyederhanaan sistem peradilan pidana dan penerapan asas kelayakan yakni keharusan bagi Penuntut umum untuk benar-benar memperhatikan kepentingan publik (public interest test) dalam memutuskan menerapkan mekanisme peneyelesaian perkara pidana di luar persidangan sehingga sumber daya penegak hukum dapat lebih difokuskan untuk penanganan perkaraperkara yang lebih berat.

\section{SARAN}

Berdasarkan kesimpulan diatas, maka dapat disampaikan rekomendasi bahwa asas kelayakan perlu segera diterima dalam sistem peradilan pidana di Indonesia dengan cara mengadopsi teori subsosialitas sebagaimana tercantum dalam Pasal 9a Sr. dan mengadopsi mekanisme penyelesaian perkara tindak pidana korupsi di luar persidangan dalam bentuk transaksi dengan model komposisi, dengan disertai adanya modifikasi penambahan pokok-pokok pemikiran adaptasi bagi sistem hukum Indonesia

\section{REFERENSI}

Albrecht, H. J. (2001). A Comparative Study of European Criminal Justice Systems. South African Law Commission.

Asshiddiqie, J. (1996). Pembaharuan Hukum Pidana: Studi tentang Bentuk-bentuk Pidana dalam Tradisi Hukum Fiqh dan Relevansinya Bagi Usaha Pembaharuan KUHP Nasional. Angkasa.

Brants-Langeraar, C. H. (2007). Consensual Criminal Procedures: Plea and Confession Bargaining and Abbreviated Procedures to Simplify Criminal Procedure. Electronic Journal of Comparative Law (EJCL), 11(1), 21. www.ejcl.org

Brants, C., \& Franken, S. (2009). The Protection of Fundamental Human Rights in Criminal Process. Utrecht Law Review, 5(2), 56.

Crijns, J. H. (2011). Witness Agreements in Dutch Criminal Law. Seminar Internasional Dan Focus Group Discussion Tentang The Protection of Whistleblowers as Justice Collaborators, 2.

Dunn, G. (n.d.). 2015 Year End Update on Corporate Non Prosecution Agreements and Deferred Prosecution Agreements. www.gibsondunn.com/publication/pages/2015year-end-update-Non-Prosecution-agreementand-deferred-prosecution-agreements.

Jacobs, P., \& Kampen, P. van. (2014). `Dutch 'ZSM Settlements' in the Face of Procedural Justice: The Sooner the Better'. Utrecht Law Review, 10(4), 75 . 
Jehle, J.-M. (2005). The Function of Public Prosecution from a European Comparative Perspective : How International Research Can Contribute to the Development of Criminal Justice. Konferensi UNDP-POGAR, 7.

Kempen, P. H. van. (2009). The Protection of Human Rights in Criminal Law Procedure in The Netherlands. Electronic Journal of Comparative Law, 13(2), 12. http://www.ejcl.org

Krauss, R. (2012). The Theory of Prosecutorial Discretion in Federal Law: Origin and Developments. Seton Hall Circuit Review, 6(1), 2.

Kyprianou, D. (n.d.). Comparative Anaysis of Prosecution Systems (Part II): The Role of Prosecution Services in Investigation and Prosecution Principles and Policies. www.law.gov.cy

Langbein, J. H. (1973). The Origins of Public Prosecution at Common Law. American Journal Of Legal History, XVII, 318.

Langer, Maximo, Sklansky, \& Alan, D. (2016). Prosecutors and Democracy: A Cross-Nation Study. Cambridge University Press.

Luna, E., \& Wade, M. (2010). Prosecutors as Judges. Washington and Lee Law Review, 67(4), 1429.

McConville, M., Sanders, A., \& Leng, R. (1996). Prosecution in Common Law Jurisdictions. Aldershot.

Nijboer, J. F. (1999). Introduction To Dutch Law (3rd ed.rev). Kluwer Law International.

Novokmet, A. (2016). The Right of a Victim to a Review of a Decision not to Prosecute as Set out in Article 11 of Directive 2012/29/EU and an Assessment of its Transposition in Germany, Italy, France and Croatia. Utrecht Law Review, 12(1), 87.

Organisation for Economic Cooperation and Development (OECD). (2017). Implementing The OECD Anti-Bribey Convention, Phase 4 Report : United Kingdom. Organisation for Economic Cooperation and Development. www.oecd.or/corruption
Peter Mahmud Marzuki. (2009). Penelitian Hukum, Edisi Pertama Cetakan Kelima. Kencana.

Remmelink, J. (2003). Hukum Pidana, Komentar Atas Pasal-pasal Terpenting dari Kitab UndangUndang Hukum Pidana Belanda dan Padananya dalam Kitab Undang-Undang Hukum, translated Tristam Pascal Moeljono Pidana Indonesia. PT Gramedia Pustaka Utama.

Saifullah. (2004). Konsep Dasar Metode Penelitian Dalam Proposal Skripsi. UIN Malang.

Summers, S. J. (2007). Fair Trials, The European Criminal Procedural Tradition and The European Court of Human Rights. Hart Publishing.

Tak, P. J. P. (2003). The Dutch Criminal Justice System: Organization and Operation (2nd Editio). Boom Juridische.

Tak, P. J. P. (2006). Methods of Diversion Used By the Prosecution Service in the Netherlands and Other Western European Countries. 135th International Senior Seminar Visiting Experts `Papers, Hosted by the United Nations Asia and Far East Institute (UNAFEI) for the Prevention of Crimes and the Treatment of Offender, 54.

UN Office on Drugs and Crime. (2007). Handbook of Basic Principles and Promising Practices on Alternatives to Imprisonment. UN Publication. 